\title{
Effect of Carbon Dioxide Injection on Physiochemical Properties and Saccharification of Extruded Corn Starch for Fermentation Substrate Preparation
}

\author{
Lin Myat and Gi-Hyung Ryu* \\ Department of Food Science and Technology, Kongju National University, Yesan, Chungnam 340-802, Korea
}

\begin{abstract}
The objective of this research was to investigate the effect of carbon dioxide injection during extrusion process at different melt temperatures 95,115 and $135^{\circ} \mathrm{C}$ on physiochemical properties and enzymatic saccharification of extruded corn starch for fermentation substrate preparation. Carbon dioxide gas was injected during extrusion at the flow rate of $500 \mathrm{ml} / \mathrm{min}$ and pressure of $3 \mathrm{MPa}$. For enzymatic saccharification, $0.8 \% \alpha$-amylase enzyme was used at different saccharification periods. After extrusion, physiochemical properties and reducing sugar content were measured. Carbon dioxide injection had positive effects on breaking strength, elastic modulus, expansion ratio, specific length, piece density, water absorption index, water solubility index, free amino nitrogen and reducing sugar content (after saccharification) at melt temperatures 115 and $135^{\circ} \mathrm{C}$. However, significant decrease $(p<0.05)$ in specific mechanical energy input was obtained at only $135^{\circ} \mathrm{C}$. The data clearly showed that carbon dioxide injection gave significantly increased $(p<0.05)$ reducing sugar content at melt temperatures 115 and $135^{\circ} \mathrm{C}$ for fermentation substrate preparation.
\end{abstract}

Keywords: Extrusion process; Carbon dioxide injection; Corn starch; $\alpha$-amylase; Saccharification

\section{Introduction}

Starch-containing crops form an important constituent of the human diet and a large proportion of food consumed by the world's population originates from them. The increasing number of commercially marketed products has created a demand for health-functional ingredients that are stable and convenient to use in formulation. Highly porous solids are easily dispersible in liquid formulations and can be used as a carrier for health-functional ingredients. The highly porous structure of extruded products make the process suitable for encapsulating enzymes, flavor and color additives and health functional compounds in a carbohydrate matrix. Besides the use of the starch-containing plant parts directly as a food source, starch is harvested and used in chemical or enzymatic processes for industrial purposes. Although there are a large number of plants able to produce starch, only a few plants are important for industrial starch processing. The major industrial sources are corn, tapioca, potato, and wheat.

Extrusion-cooking continues to be used by the food and feed industry. Recently, the use of an extruder has been investigated as a continuous reactor for enzymatic modification of starches. Extrusion process has been applied for liquefying different kinds of starches to reduce saccharifying time for glucose syrup production or fermentation substrate preparation. A large-scale starch processing industry has emerged in the last century. Currently, we have seen a shift from conventional extrusion of starch to the use of $\mathrm{CO}_{2}$ injection during extrusion in the production of starch hydrolysates, glucose and fructose syrups for fermentation. In conventional extrusion, liquid water has been used at high pressure in the melt to expand the products and it is converted to vapor on pressure reduction as the extrudate exits the die. In order to generate adequate steam to puff the extrudate, a high temperature and pressure is required at the entrance to the die so that flash evaporation will occur [1]. The conditions used in conventional extrusion of snack foods and, cereals would be detrimental to heat sensitive ingredients such as functional proteins, vitamins, flavors, and natural plant derived colors may be incorporated in the melt. In addition, steam-puffed extrudates have coarse and nonuniform cellular structures with cell sizes in the range of 1-3 $\mathrm{mm}$, while expansion ratios in the range of 9-12. Moreover, steam-puffed extrusion is difficult to control pore size and product density of the extrudates [2]. Ferdinand et al. [3] studied structure formation in maize grits, wheat starch, and dehydrated potato granules in the absence of steam expansion by injecting low pressure $\mathrm{CO}_{2}$ into the extruder. Cell size, cells per unit area, and expansion ratio of extrudates were more easily controlled in the supercritical fluid extrusion process as compared to traditional extrusion [4].

The main advantage of $\mathrm{CO}_{2}$ injection in the barrel of an extruder is its function as plasticizer, which allows the processing of molecules which would otherwise be too fragile to withstand the mechanical stresses and the operating temperatures of a standard extrusion process. In addition, the dissolved $\mathrm{CO}_{2}$ acts as foaming agent during expansion through the die. It is, therefore, to control pore generation and growth by controlling the operating conditions [5]. Therefore, this experiment was conducted to determine the effect of $\mathrm{CO}_{2}$ injection on physiochemical properties and the saccharification yield of extruded corn starch using a-amylase enzyme for fermentation substrate preparation.

*Corresponding author: Gi-Hyung Ryu, Department of Food Science and Technology, Kongju National University, Yesan, Chungnam 340-802, Korea, Tel: 82-41-330-1484; Fax: 82-41-335-5944; E-mail: ghryu@kongju.ac.kr

Received December 13, 2012; Accepted January 22, 2013; Published January 25, 2013

Citation: Myat L, Ryu GH (2013) Effect of Carbon Dioxide Injection on Physiochemical Properties and Saccharification of Extruded Corn Starch for Fermentation Substrate Preparation. J Microb Biochem Technol 5: 018-024. doi:10.4172/1948-5948.1000093

Copyright: (C) 2013 Myat L, et al. This is an open-access article distributed unde the terms of the Creative Commons Attribution License, which permits unrestricted use, distribution, and reproduction in any medium, provided the original author and source are credited 


\section{Materials and Methods}

\section{Extrusion process}

Corn starch provided by Samyang Genex Co. (Korea) was used for extrusion. Extrusion was conducted in twin-screw extruder (THK31T, Incheon Machinery Co., Incheon, Korea). All experiments were conducted at screw speed of $150 \mathrm{rpm}$, feed rate of $100 \mathrm{~g} / \mathrm{min}$, water injection rate of $24.73 \mathrm{~g} / \mathrm{min}$, die diameter of $3 \mathrm{~mm}$ and feed moisture content of $30 \%$. Carbon dioxide injection flow rate was $500 \mathrm{ml} / \mathrm{min}$ and $\mathrm{CO}_{2}$ pressure was $3 \mathrm{MPa}$. Melt temperature was controlled at 95,115 and $135^{\circ} \mathrm{C}$ with and without $\mathrm{CO}_{2}$ injection. The corn starch extrudates were dried and grinded into powder with a particle size of less than $0.5 \mathrm{~mm}$ and used as samples for physiochemical analysis and saccharification process.

\section{Mechanical properties}

Mechanical properties were determined by a texture analyzer (Compac-100, Sun Scientific Co., Ltd., Tokyo, Japan). The apparent elastic modulus $\left(\mathrm{E}_{\text {app }}\right)$ and breaking strength $\left(\mathrm{F}_{\mathrm{bs}} / \mathrm{S}\right)$ in bending tests of extruded corn starch were evaluated by the method described by [6]. The $\mathrm{E}_{\text {app }}$ in bending extrudates between two supports was determined as the extrudates strand deformed in bending until fracture occurred. $\mathrm{E}_{\text {app }}$ was calculated as equation:

$$
\mathrm{E}_{\text {app }}=(\mathrm{dF} / \mathrm{dI})\left(64 \mathrm{~d}^{3} / 48 \pi \mathrm{D}^{4}\right)
$$

Where $\mathrm{dF} / \mathrm{dI}=$ the slope of the linear section of the force-distance curve; $d=$ the distance between two supports $(30 \mathrm{~mm}) ; \mathrm{D}=$ the diameter of extrudates. Breaking strength $\left(\mathrm{F}_{\mathrm{bs}} / \mathrm{S}\right)$ in bending was calculated as maximum peak divided by the cross-sectional area of extrudates. Extrudate sample was cut at $\sim 42 \mathrm{~mm}$ length. The single of extrudate was placed on the two support bars perpendicular to the probe. Each value was presented as an average of ten readings.

\section{Physical properties}

The expansion ratio was determined as the diameter of extrudates divided by the diameter of the die exit $(3 \mathrm{~mm})$ [6]. The specific length of extruded corn starch $\left(\mathrm{L}_{\mathrm{sp}}\right)$ was evaluated as the straight length of extrudates divided by the equivalent weight of extrudates [7]. The values were reported as an average of ten readings.

The piece density $\left(D_{e}\right)$ was determined as the weight of extrudates $\left(W_{e}\right)$ divided by the equivalent volume of extrudates $\left(V_{e}\right)$. The volume of extrudates $\left(V_{e}\right)$ was determined by substituting rapeseed weight $\left(W_{r}\right)$ for extrudates volume and dividing it by rapeseed density $\left(D_{r}\right)$. The piece density of each sample was calculated according to the following equation and reported as an average of five readings [6].

$$
D_{e x}=W_{e} \times \frac{D_{r}}{W_{r}}
$$

The water absorption index (WAI) was determined as the amount (g) of water absorbed by each gram of sample as described by Lee et al. [7]. One gram of extruded powder was mixed with $25 \mathrm{ml}$ of distilled water in $50 \mathrm{ml}$ centrifuge tube. The tubes were agitated in incubator shaker $(110 \mathrm{rpm})$ for 30 minutes at $30^{\circ} \mathrm{C}$. Then, the tubes were centrifuged at $3000 \mathrm{rpm}$ for 20 minutes. The water solubility index (WSI) determines the amount of free molecules leached out from the starch granule in addition to excess water. WAI and WSI were determined according to Anderson et al. [8].

WAI $(\mathrm{g} / \mathrm{g})=\frac{\text { Hydrated sample weight-Dry sample }}{\text { Dry sample weight }}$

$$
\text { WSI }(\%)=\frac{\text { Dry solid weight recovered by evaporation of the supernatant }}{\text { Dry sample weight }} \times 100
$$

\section{Specific mechanical energy input}

The specific mechanical energy (SME) input was calculated using the following equation:

$$
\mathrm{SME}=\frac{E^{V}-E^{0}}{F^{r}}
$$

Where $E$ is electric current after feed material (amperes); $E^{0}$ is initial electric current (amperes); $E^{V}$ is the voltage applied to the motor (volts) and $F^{r}$ is the feed rate supplied to extruder $(\mathrm{kg} / \mathrm{s})$.

\section{Chemical properties}

Moisture content was analyzed by the standard method [9]. Total sugar content was measured using phenol-sulfuric acid method [10] Two grams of sample was mixed with $20 \mathrm{ml}$ of $70 \%$ ethanol solution and it was extracted at $80^{\circ} \mathrm{C}$ for $2 \mathrm{hr}$. Then, the extracted mixture was centrifuged at $3000 \mathrm{rpm}$ for 20 minutes. The supernatant was decanted and it was volume made up to $40 \mathrm{ml}$ with distilled water. The sample solution $(1 \mathrm{ml})$ was mixed with $1 \mathrm{ml}$ of $5 \%$ phenol solution and $5 \mathrm{ml}$ of sulfuric acid. The mixture was left for 15 minutes for standing in the room temperature and the absorbance was read at $550 \mathrm{~nm}$. Glucose was used for standard solution. Reducing sugar content was determined as glucose according to DNS method [11]. Free Amino Nitrogen (FAN) was analyzed according to the European Brewery Convention Method [12] with modification. Raw and extruded corn starch powder (150 $\mathrm{mg}$ ) were mixed with $1.5 \mathrm{ml}$ of deionized distilled water in a $1.5 \mathrm{ml}$ microcentrifuge tube and vortexed and then centrifuged at $12,000 \mathrm{rpm}$ for 20 minutes using a high speed microcentrifuge (Micro 17TR, Hani Science Industrial Co. Ltd. Korea). The supernatant (1 ml) was mixed with $1 \mathrm{ml}$ of Ninhydrin color reagent and it was heated in boiling water bath for $16 \mathrm{~min}$. The tubes were transferred to a cold water bath and 5 $\mathrm{ml}$ of dilution reagent was added, mixed and the absorbance was read at $575 \mathrm{~nm}$ against a blank containing $1 \mathrm{ml}$ of water in place of sample.

\section{Microstructures}

Raw and extruded corn starch powders were examined with a field emission scanning electronic microscope (MIRA II LMH Tescan USA, Inc., Cranberry Township, PA). The samples were fixed in stubs containing a gold-palladium alloy before observation. All samples were examined at an accelerated voltage of $10 \mathrm{kV}$.

\section{Enzymatic hydrolysis and saccharification}

One gram of ground dried sample was suspended in $43 \mathrm{ml}$ of 20 $\mathrm{mM}$ sodium acetate-acetic acid buffer at $\mathrm{pH}$ 5.6. This mixture was supplemented with $5 \mathrm{ml}$ of $0.8 \%$ a-amylase solution and incubated in rotary shaker $(100 \mathrm{rpm})$ at $30^{\circ} \mathrm{C}$ for $0,2,4,6,8$ and $10 \mathrm{hr}$. The reducing sugar content of raw and extruded corn starch at specific time internal was determined according to DNS method [11] using 3,5-dinitrosalicylic acid. Glucose solution was used as a standard.

\section{Experimental design and statistical analysis}

Completely randomized design (CRD) was performed to determine the effect of $\mathrm{CO}_{2}$ injection during extrusion at different melt temperatures 95,115 and $135^{\circ} \mathrm{C}$. The data were analyzed by using the SAS program (Version 6.12, Statistical Analysis System). 


\section{Results and Discussion}

\section{Mechanical properties}

As shown in table $1, \mathrm{CO}_{2}$ injection during extrusion significantly affected breaking strength in bending $(\mathrm{p}<0.05)$ at melt temperature $95^{\circ} \mathrm{C}$ and also numerically decreased at 115 and $135^{\circ} \mathrm{C}$. Breaking strength decreased with $\mathrm{CO}_{2}$ injection and had a negative correlation with expansion ratio $(\mathrm{p}<0.05)$. Martinez-Serna and Villota [13] reported that breaking force depended on degree of expansion and cell wall strength. Several other researchers also demonstrated that breaking strength decreased with increasing expansion ratio (i.e., a decrease in piece density) [14-19]. Hsieh et al. [18] found that thinner cell walls with greater radial expansion were formed, and extrudates became more breakable. Our results are consistent with those observations. However, there was no significant difference at 115 and $135^{\circ} \mathrm{C}$. Elastic modulus was also affected by $\mathrm{CO}_{2}$ injection $(\mathrm{p}<0.05)$. As shown in table 1, elastic modulus significantly increased at melt temperature $95^{\circ} \mathrm{C}$ and numerically decreased at 115 and $135^{\circ} \mathrm{C}$ with increasing melt temperature and was negatively correlated with expansion ratio. Decrease in elastic modulus at 115 and $135^{\circ} \mathrm{C}$ is a positive effect for extrudates. The elastic modulus is the degree of the stiffness of extrudates, which depends on the intrinsic rigidity of the expanded matrix and on the longitudinal expansion. The lower the apparent elastic modulus in bending, the crisper is the texture of the extrudates [6].

\section{Physical properties}

Expansion ratio was significantly increased by $\mathrm{CO}_{2}$ injection $(\mathrm{p}<0.05)$ at tested melt temperatures 95,115 and $135^{\circ} \mathrm{C}$. The expansion ratio of corn starch extrudates was positively correlated with specific length at tested melt temperatures 95,115 and $135^{\circ} \mathrm{C}$. Jeong and Toledo [20] also reported that the expansion ratio of extruded rice flour with $\mathrm{CO}_{2}$ injection increased with increasing $\mathrm{CO}_{2}$ injection pressure and decreased with increasing piece density. Our results agreed with their observation (Table 1).

Specific length was significantly increased by $\mathrm{CO}_{2}$ injection at
115 and $135^{\circ} \mathrm{C}(\mathrm{p}<0.05)$. Higher melt temperature with $\mathrm{CO}_{2}$ injection caused the feed material to melt fully and also reduced the melt viscosity, resulting in increased specific length of the extrudates. Present results are consistent with those of our previous study in which the specific length was decreased with increase in SME input [6]. Piece density of extrudates with $\mathrm{CO}_{2}$ injection at $95^{\circ} \mathrm{C}$ was significantly $(\mathrm{p}<0.05)$ lower than those of extrudates without $\mathrm{CO}_{2}$ injection. However, there was no significant difference $(\mathrm{p}>0.05)$ at 115 and $135^{\circ} \mathrm{C}$.

The effect of $\mathrm{CO}_{2}$ injection on water solubility index (WSI) and water absorption index (WAI) is shown in table 2. WSI of extruded corn starch with $\mathrm{CO}_{2}$ injection was significantly increased $(\mathrm{p}<0.05)$ at melt temperature $135^{\circ} \mathrm{C}$ and also increased at both melt temperatures 95 and $115^{\circ} \mathrm{C}$. Our results agree with those of Jeong and Toledo [20]. WSI of the rice flour significantly increased from $5.12 \%$ to $12.73 \%$ as $\mathrm{CO}_{2}$ injection pressure increased from 0.1 to $0.6 \mathrm{MPa}$. WSI is related to the amount of low molecular weight products of starch degradation which are easily soluble because of reduced entanglement [8]. WSI values reflect the rate of penetration of water into the solid particles and diffusion of the soluble components outside of the particles. It is also a function of extent of dextrinization of starch. In general, WSI is often used as an indicator of degradation of molecular components because its measurement can be known by the conversion degree of starch during extrusion cooking. This conversion degree is amount of soluble polysaccharide released from the starch after extrusion. In this study, the increase in the melt temperature with $\mathrm{CO}_{2}$ injection caused an increase in the macro-molecular degradation during extrusion process and resulting in an increase in WSI of extruded corn starch. WSI usually increases when starch chains degrade into smaller fragments. Low temperature and high moisture content might help reduce structural degradation during extrusion $[3,21,22]$. WSI had a tendency to increase as melt temperature increased with $\mathrm{CO}_{2}$ injection. Therefore, it is reasonable that our extruded corn starch with $\mathrm{CO}$ injection would be highly solubilized (dispersed) in water giving a high WSI (Table 2).

Water absorption index (WAI) measures the volume occupied by the starch after swelling in excess water, which maintains the integrity

\begin{tabular}{|c|c|c|c|c|c|c|}
\hline Melt temp. $\left({ }^{\circ} \mathrm{C}\right)$ & $\mathrm{CO}_{2}$ injection & Breaking strength $\left(\mathrm{N} / \mathrm{m}^{2}\right)$ & Elastic modulus(N/m²) & Expansion ratio & $\begin{array}{l}\text { Specific length } \\
(\mathrm{m} / \mathrm{kg})\end{array}$ & $\begin{array}{l}\text { Piece density } \\
\left(\mathrm{g} / \mathrm{cm}^{3}\right)\end{array}$ \\
\hline \multirow[t]{2}{*}{95} & With $\mathrm{CO}_{2}$ injection & $3.14 \mathrm{E}+0.5^{b}$ & $7.28 \mathrm{E}+05^{\mathrm{b}}$ & $1.69 \pm 0.05^{\mathrm{a}}$ & $53.97 \pm 1.88^{d}$ & $0.63 \pm 0.08^{b}$ \\
\hline & Without $\mathrm{CO}_{2}$ injection & $5.71 \mathrm{E}+0.5^{\mathrm{a}}$ & $3.55 \mathrm{E}+06^{\mathrm{a}}$ & $1.54 \pm 0.03^{b}$ & $53.91 \pm 1.95^{d}$ & $0.85 \pm 0.06^{\mathrm{a}}$ \\
\hline \multirow[t]{2}{*}{115} & With $\mathrm{CO}_{2}$ injection & $1.76 \mathrm{E}+0.5^{\mathrm{c}}$ & $4.95 \mathrm{E}+05^{\mathrm{bc}}$ & $1.53 \pm 0.07^{b}$ & $57.91 \pm 2.09^{c}$ & $0.63 \pm 0.04^{b}$ \\
\hline & Without $\mathrm{CO}_{2}$ injection & $1.84 \mathrm{E}+0.5^{c}$ & $6.06 \mathrm{E}+05^{\mathrm{bc}}$ & $1.4 \pm 0.09^{c}$ & $53.02 \pm 0.98^{d}$ & $0.66 \pm 0.02^{b}$ \\
\hline \multirow[t]{2}{*}{135} & With $\mathrm{CO}_{2}$ injection & $6.24 \mathrm{E}+04^{\mathrm{d}}$ & $2.92 \mathrm{E}+05^{c}$ & $1.71 \pm 0.04^{\mathrm{a}}$ & $81.98 \pm 3.52^{\mathrm{a}}$ & $0.35 \pm 0.03^{c}$ \\
\hline & Without $\mathrm{CO}_{2}$ injection & $6.50 \mathrm{E}+04^{\mathrm{d}}$ & $4.19 \mathrm{E}+05^{\mathrm{bc}}$ & $1.6 \pm 0.15^{b}$ & $70.46 \pm 2.52^{b}$ & $0.37 \pm 0.02^{c}$ \\
\hline
\end{tabular}

Means of ten replications, based on least significant difference (LSD) procedure at $\alpha=0.05$ level. Means with the same letter in the same column are not significantly different.

Table 1: The mechanical and physical properties of extruded corn starch at different melt temperatures.

\begin{tabular}{|c|c|c|c|c|}
\hline Melt temperature $\left({ }^{\circ} \mathrm{C}\right)$ & $\mathrm{CO}_{2}$ injection & 'WSI (\%) & ${ }^{2} \mathrm{WAl}(\mathbf{g} / \mathrm{g})$ & ${ }^{3} \mathrm{SME}(\mathbf{k J} / \mathbf{k g})$ \\
\hline \multirow[t]{2}{*}{95} & With $\mathrm{CO}_{2}$ injection & $3.60 \pm 0.35^{\text {de }}$ & $2.51 \pm 0.13^{d}$ & $534.91 \pm 8.25^{\mathrm{a}}$ \\
\hline & Without $\mathrm{CO}_{2}$ injection & $3.23 \pm 0.08^{e}$ & $2.53 \pm 0.06^{d}$ & $542.81 \pm 4.89^{a}$ \\
\hline \multirow[t]{2}{*}{115} & With $\mathrm{CO}_{2}$ injection & $4.90 \pm 0.84^{c}$ & $3.64 \pm 0.22^{c}$ & $306.98 \pm 1.77^{b}$ \\
\hline & Without $\mathrm{CO}_{2}$ injection & $4.10 \pm 0.39^{d c}$ & $4.55 \pm 0.87^{b}$ & $308.12 \pm 6.56^{b}$ \\
\hline \multirow[t]{2}{*}{135} & With $\mathrm{CO}_{2}$ injection & $7.24 \pm 0.24^{a}$ & $5.03 \pm 0.02^{\mathrm{ab}}$ & $169.55 \pm 1.09^{d}$ \\
\hline & Without $\mathrm{CO}_{2}$ injection & $6.51 \pm 0.17^{b}$ & $5.23 \pm 0.31^{a}$ & $181.29 \pm 5.99^{c}$ \\
\hline Raw corn starch & $0.23 \pm 0.02^{f}$ & $0.75 \pm 0.03^{e}$ & - & \\
\hline
\end{tabular}

${ }^{1}$ water solubility index, ${ }^{2}$ water absorption index and ${ }^{3}$ specific mechanical energy input

Means of three replications, based on least significant difference (LSD) procedure at $\alpha=0.05$ level. Means with the same letter in the same column are not significantly different

Table 2: Water solubility index, water absorption index and specific mechanical energy input of extruded corn starch. 
of starch in aqueous dispersion [23]. WAI of extruded corn starch with $\mathrm{CO}_{2}$ injection was significantly decreased $(\mathrm{p}<0.05)$ at $115^{\circ} \mathrm{C}$ and also decreased at 95 and $135^{\circ} \mathrm{C}$. The WAI is a function of the internal voids in the milled sample powder and the thickness of the cell walls of the voids. Since the extrusion was carried out, the raw material is a pre-gelatinized starch. The differences can be attributed primarily to physical effect related to the structure of voids in the solid. Thus, significantly decreased in WAI of extruded corn starch at $115^{\circ} \mathrm{C}$ can be attributed to $\mathrm{CO}_{2}$ injection. The decrease in WAI and increase in WSI (Table 2) is an indication that extrusion with $\mathrm{CO}_{2}$ injection may have accelerated degradation of starch granules and release of watersoluble compounds during extrusion. This change is more susceptible to enzymatic digestion. Our results agreed with Whalen [24] who reported that the WAI and WSI of extruded corn starch were also higher than those of raw corn starch due to swelling of highly degraded starch (Table 2).

The influence of $\mathrm{CO}_{2}$ injection at different melt temperatures on specific mechanical energy (SME) input is shown in table $2 . \mathrm{CO}_{2}$ injection during extrusion decreased SME input at tested melt temperatures. There was no significant difference in both melt temperatures 95 and $115^{\circ} \mathrm{C}$. However, SME input was significantly decreased by $\mathrm{CO}_{2}$ injection $(\mathrm{p}<0.05)$ at $135^{\circ} \mathrm{C}$. The higher the melt temperature, the lower the SME input for both with and without $\mathrm{CO}_{2}$ injection. In this experiment, changes in SME input caused by melt temperature had the same pattern as studied by other authors Ryu et al. [6] and Brent et al. [25] who reported that SME input was decreased with the increase in melt temperature. Therefore, SME input was decreased with increase in melt temperature with $\mathrm{CO}_{2}$ injection. Higher SME input at lower melt temperature is explained by the higher viscosity of the melt at this temperature since SME input is the mechanical energy consumed to rotate the screws plus viscous melt [26].

\section{Chemical properties}

The moisture contents of raw and extruded corn starch with and without $\mathrm{CO}_{2}$ injection ranged between $8.89 \%$ and $12.69 \%$, those obtained were less than $20 \%$ and were acceptable [27]. Total sugar and reducing sugar contents of raw and extruded corn starch with and without $\mathrm{CO}_{2}$ injection are shown in table 3 . There was no significant difference in total sugar and reducing sugar contents of extruded corn starch with and without $\mathrm{CO}_{2}$ injection. However, extruded corn starch with $\mathrm{CO}_{2}$ injection can numerically increase total sugar and reducing sugar than those without $\mathrm{CO}_{2}$ injection at each melt temperature.

$\mathrm{CO}_{2}$ injection during extrusion can significantly increase $(\mathrm{p}<0.05)$ the amount of free amino nitrogen (FAN) at melt temperatures 95, 115 and $135^{\circ} \mathrm{C}$ (Table 3 ). Researchers have found that one of the factors limiting the production of high levels of ethanol by brewing yeast is of nutritional deficiency [28]. When a nitrogen source is supplemented in the fermentation system, the nutritional supplement can promote rapid fermentation to a higher ethanol level without the need to genetically modify yeast. Therefore, FAN in the sample is important for yeast performance. The higher the FAN in the fermented slurry, the faster is the fermentation process. Our results supported the effect of FAN on ethanol fermentation efficiency from field-sprouted sorghum as described by Yan et al. [29]. Casey et al. [30] made the same conclusion about the effect of FAN on fermentation efficiency of high gravity brewing from wheat. Therefore, FAN content in a sample could be a useful indicator of a sample's performance in ethanol fermentation. It was also showed that similar results agree with results reported by several other researchers [30-32]. Mullins and Nesmith [33] studied ethanol fermentation with high-tannin sorghum and revealed that the addition of nitrogen accelerated the ethanol fermentation rate. Moreover, Diammonium Phosphate (DAP) is widely used as Yeast Assimilable Nitrogen (YAN). The assimilable nitrogen was found to be related to FAN and the addition of DAP increased fermentation rate [34,35].

\section{Microstructures}

Microstructures of raw and extruded corn starch powder are shown

\begin{tabular}{|c|c|c|c|c|c|}
\hline Melt temperature $\left({ }^{\circ} \mathrm{C}\right)$ & $\mathrm{CO}_{2}$ injection & ${ }^{1} \mathrm{MC}(\%)$ & Total sugar $(\mathrm{mg} / \mathrm{g})$ & Reducing sugar (mg/g) & Free amino nitrogen $(\mathrm{mg} / \mathrm{ml})$ \\
\hline \multirow[t]{2}{*}{95} & With $\mathrm{CO}_{2}$ injection & $8.89 \pm 0.09^{e}$ & $11.00 \pm 0.16^{a}$ & $0.36 \pm 0.03^{d}$ & $254.10 \pm 1.62^{c}$ \\
\hline & Without $\mathrm{CO}_{2}$ injection & $9.02 \pm 0.05^{\mathrm{e}}$ & $8.66 \pm 1.03^{\mathrm{abc}}$ & $0.36 \pm 0.01^{d}$ & $202.46 \pm 1.86^{\mathrm{d}}$ \\
\hline \multirow[t]{2}{*}{115} & With $\mathrm{CO}_{2}$ injection & $11.12 \pm 0.02^{b}$ & $10.17 \pm 1.62^{\mathrm{ab}}$ & $0.86 \pm 0.03^{a}$ & $202.68 \pm 2.03^{d}$ \\
\hline & Without $\mathrm{CO}_{2}$ injection & $10.12 \pm 0.59^{d}$ & $7.94 \pm 2.29^{b c}$ & $0.85 \pm 0.07^{a}$ & $164.11 \pm 2.43^{e}$ \\
\hline \multirow[t]{3}{*}{135} & With $\mathrm{CO}_{2}$ injection & $11.49 \pm 0.10^{b}$ & $7.42 \pm 1.54^{c}$ & $0.81 \pm 0.04^{\mathrm{ab}}$ & $313.03 \pm 1.10^{\mathrm{a}}$ \\
\hline & Without $\mathrm{CO}_{2}$ injection & $10.65 \pm 0.01^{c}$ & $7.97 \pm 1.34^{\text {bc }}$ & $0.76 \pm 0.03^{b}$ & $128.59 \pm 2.50^{f}$ \\
\hline & Raw corn starch & $12.69 \pm 0.04^{a}$ & $2.25 \pm 0.25^{d}$ & $0.50 \pm 0.09^{c}$ & $276.40 \pm 1.6^{\mathrm{b}}$ \\
\hline
\end{tabular}

${ }^{1}$ moisture content

Means of three replications, based on least significant difference (LSD) procedure at $\alpha=0.05$ level. Means with the same letter in the same column are not significantly different

Table 3: Chemical properties of raw and extruded corn starch at different melting temperatures.

\begin{tabular}{|c|c|c|c|c|c|c|}
\hline \multirow[t]{2}{*}{ Melt temperature $\left({ }^{\circ} \mathrm{C}\right)$} & \multirow{2}{*}{$\mathrm{CO}_{2}$ injection } & \multicolumn{5}{|c|}{ Saccharification period (hr) } \\
\hline & & 2 & 4 & 6 & 8 & 10 \\
\hline \multirow[t]{2}{*}{95} & With $\mathrm{CO}_{2}$ injection & $75.25^{c}$ & $112.41^{d}$ & $123.35^{c}$ & $144.00^{d c}$ & $147.31^{\mathrm{b}}$ \\
\hline & Without $\mathrm{CO}_{2}$ injection & $73.94^{c}$ & $107.61^{d}$ & $123.18^{c}$ & $134.08^{d}$ & $140.15^{b}$ \\
\hline \multirow[t]{2}{*}{115} & With $\mathrm{CO}_{2}$ injection & $137.62^{\mathrm{a}}$ & $145.48^{a}$ & $158.30^{\mathrm{a}}$ & $186.99^{a}$ & $174.54^{a}$ \\
\hline & Without $\mathrm{CO}_{2}$ injection & $72.73^{c}$ & $120.83^{c}$ & $120.04^{c}$ & $150.34^{c}$ & $154.63^{b}$ \\
\hline \multirow[t]{2}{*}{135} & With $\mathrm{CO}_{2}$ injection & $113.77^{b}$ & $137.28^{b}$ & $150.51^{a}$ & $172.78^{b}$ & $146.69^{b}$ \\
\hline & Without $\mathrm{CO}_{2}$ injection & $73.44^{c}$ & $121.21^{c}$ & $138.44^{b}$ & $148.54^{c}$ & $141.97^{b}$ \\
\hline Raw corn starch & $2.09^{d}$ & $4.34^{f}$ & $9.66^{d}$ & $11.95^{\mathrm{e}}$ & $20.12^{c}$ & \\
\hline
\end{tabular}

Means of three replications, based on least significant difference (LSD) procedure at $\alpha=0.05$ level. Means with the same letter in the same column are not significantly different

Table 4: Reducing sugar content $(\mathrm{mg} / \mathrm{g})$ of raw and extruded corn starch at different saccharification periods. 
Citation: Myat L, Ryu GH (2013) Effect of Carbon Dioxide Injection on Physiochemical Properties and Saccharification of Extruded Corn Starch for Fermentation Substrate Preparation. J Microb Biochem Technol 5: 018-024. doi:10.4172/1948-5948.1000093
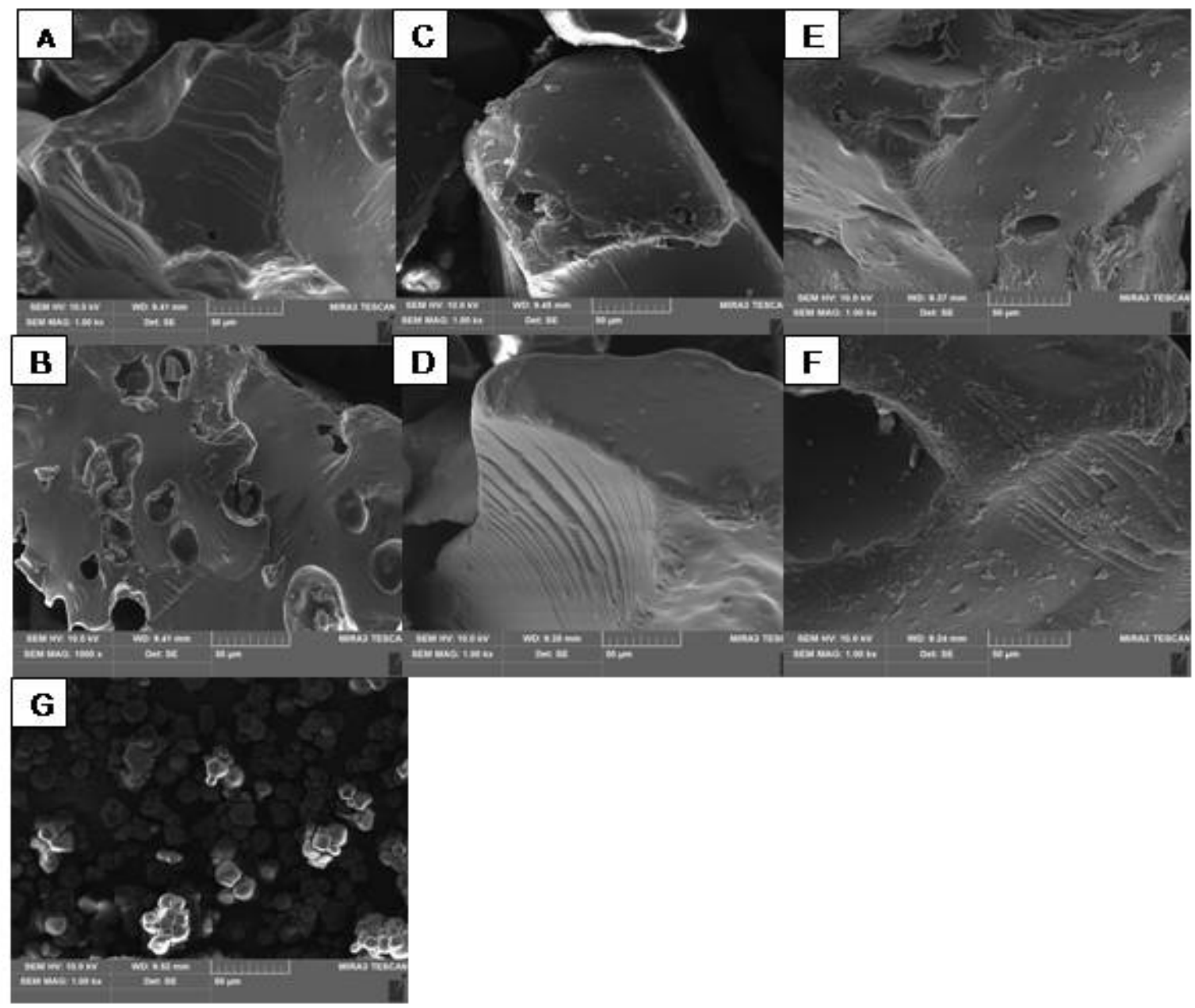

Figure 1: Microstructures of raw and extruded corn starch. A) $95^{\circ} \mathrm{C}$ with $\left.\mathrm{CO}_{2} ; \mathrm{B}\right) 95^{\circ} \mathrm{C}$ without $\mathrm{CO}_{2} ;$ C) $115^{\circ} \mathrm{C}$ with $\mathrm{CO}_{2} ;$ D) $115^{\circ} \mathrm{C}$ without $\left.\mathrm{CO}_{2} ; \mathrm{E}\right) 135^{\circ} \mathrm{C}$ with $\left.\mathrm{CO}_{2} ; \mathrm{F}\right)$ $135^{\circ} \mathrm{C}$ without $\mathrm{CO}_{2}$ and $\mathbf{G}$ ) raw corn starch.

in figure 1 . The surface of the extruded corn starch powder without $\mathrm{CO}_{2}$ injection at melt temperatures 115 and $135^{\circ} \mathrm{C}$ were very smooth without cracks. On the other hand, extruded corn starch with $\mathrm{CO}_{2}$ injection had porous structures with crackers and holes on the particle surface (Figures 1C and 1E), which could be caused by water and $\mathrm{CO}_{2}$ expansion and evaporation during extrusion. These holes make extruded corn starch granules more susceptible to enzymatic digestion because water and enzyme can more easily enter starch granules through these pores, which confirmed by the increase in reducing sugar content at saccharification periods $(2-8 \mathrm{hr})$ at 115 and $135^{\circ} \mathrm{C}$. Extruded corn starch with $\mathrm{CO}_{2}$ injection has superior solvation power and could deeply penetrate and distribute corn starch particles during extrusion process. As a result molten corn starch exits the die; the flash of $\mathrm{CO}_{2}$ produces expanded extrudates with porous structures. In conventional extrusion, water was normally used as physical blowing agent. $\mathrm{CO}_{2}$ injection in the barrel of an extruder functions as plasticizer and allows the processing of molecules which would otherwise be too fragile to withstand the mechanical stress and the operating temperature of a standard extrusion process. Therefore, extrusion with $\mathrm{CO}_{2}$ injection could effectively damage the native corn starch structures and increase their surface area. Zhan et al. [36] also reported that the injection of supercritical-fluid carbon dioxide during extrusion process increased the surface area of sorghum starch availability for fermentation.

\section{Enzymatic hydrolysis and saccharification}

Reducing sugar content of the raw and extruded corn starch after $10 \mathrm{hr}$-saccharification periods using $0.8 \%$ a-amylase was measured. As shown in table $4, \mathrm{CO}_{2}$ injection significantly increased $(\mathrm{p}<0.05)$ the production of reducing sugar by increasing the incubation period (2-8 hr) at 115 and $135^{\circ} \mathrm{C}$. This can be explained by effective damage of native starch structures after extrusion which resulted in higher dextrinization and increased the amount of soluble polysaccharide. Reducing sugar content was increased with the decrease in the moisture content of the extruded corn starch (Tables 3 and 4). These data agreed with Shin et al. [37]. However, at $10 \mathrm{hr}$-saccharification periods, the production of reducing sugar decreased at these temperatures. Despite the higher initial reducing sugar content in the sample extruded with $\mathrm{CO}_{2}$ injection at $115^{\circ} \mathrm{C}$, more increase in the reducing sugar content after saccharification was observed in the samples extruded without $\mathrm{CO}_{2}$ injection. Colona et al. [26] stated that a low water absorption index indicated the restricted water accessibility of extruded starch to form suspension or solution. This condition might restrict to the 
easiness of dextrin structure which goes into solution as a substrate for enzymatic reaction. The higher the initial reducing sugar content, the lower increase of the reducing sugar content was observed after saccharification [38]. It is known that in the expense amount of glucose, $\alpha$-amylase can easily form reversion products like maltose and isomaltose that would be counted as reducing sugar. Our results agreed with this observation (Table 3). The increase of the reducing sugar after saccharification was smaller for the extruded sample with $\mathrm{CO}_{2}$ injection than those of extruded sample without $\mathrm{CO}_{2}$ injection (Table 4). However, high reducing sugar content was produced by extruded corn starch with $\mathrm{CO}_{2}$ injection during extrusion at 115 and $135^{\circ} \mathrm{C}$. Based on our results and our previous observation, water solubility and absorption of extruded corn starch was higher than those of raw corn starch due to molecular fragmentation during the high shear and high temperature extrusion and due to swelling of highly degraded starch. Therefore, the amount of reducing sugar production from extruded corn starch with and without $\mathrm{CO}_{2}$ injection was significantly $(\mathrm{p}<0.05)$ higher than those of raw corn starch at tested melt temperatures and saccharification periods. Extrusion with $\mathrm{CO}_{2}$ injection can be used as a physical pretreatment method for fermentation substrate preparation.

\section{Conclusion}

Extrusion of corn starch with $\mathrm{CO}_{2}$ injection at different melt temperatures was the most significant factor affecting all the product variables investigated. Low value of breaking strength, elastic modulus, piece density and water absorption index and high value of expansion ratio, specific length, water solubility index and reducing sugar production after saccharification were obtained by extrusion at melt temperatures 115 and $135^{\circ} \mathrm{C}$. Finally, extrusion with $\mathrm{CO}_{2}$ injection at melt temperatures 115 and $135^{\circ} \mathrm{C}$ could effectively gelatinize and degrade the native corn starch granules which resulted in higher dextrinization and subsequently increased the reducing sugar content after saccharification periods $(2-8 \mathrm{hr})$ for fermentation substrate preparation.

\section{Acknowledgement}

This research was supported by Training Program of Graduate Students in Regional Innovation through the National Research Foundation of Korea (NRF) funded by the Ministry of Education, Science and Technology (2012307KJ).

\section{References}

1. Chinnaswamy R, Hanna MA (1988) Relationship between amylose content and extrusion-expansion properties of corn starches. Cereal Chem 65: 138-143.

2. Barrett AM, Peleg M (1992) Cell size distribution of puffed corn extrudates. J Food Sci 57: 146-148.

3. Ferdinand JM, Lai-fook RA, Ollet AL, Smith AC, Clark SA (1990) Structure formation by carbon dioxide injection in extrusion cooking. J Food Eng 11: 209224

4. Bladwin DF, Park CB, Suh NP (1996) An extrusion system for the processing of microcellular polymer sheets: shaping and cell growth control. Polymer Engineering \& Science 36: 1425-1435

5. Sauceau M, Fages J, Common A, Nikitine C, Rodier E (2011) New challenges in polymer foaming: A review of extrusion processes assisted by supercritical carbon dioxide. Prog Polym Sci 36: 749-766.

6. Ryu GH, Ng PKW (2001) Effects of selected process parameters on expansion and mechanical properties on wheat flour and whole cornmeal extrudates. Starch-Stärke 53: 147-154

7. Lee EY, Ryu GH, Lim ST (1999) Effects of Processing Parameters on Physical Properties of Corn Starch Extrudates Expanded Using Supercritical $\mathrm{CO}_{2}$ Injection. Cereal Chem 76: 63-69.

8. Anderson RA, Conway HF, Pfeifer VF, Griffin EL (1969) Gelatinization of corn grits by roll and extrusion-cooking. Cereal Sci Today 14: 4-12.

9. AOAC (1995) Official Method Analysis of the AOAC. (16thedn), Association of
Official Analytical Chemists, Washington DC, USA

10. Dubois M, Gilles KA, Hamilton JK, Rebers PA, Smith F (1956) Colorimetric method for determination of sugars and related substances. Anal Chem 28: 350-356.

11. Miller GL (1959) Use of dinitrosalicylic acid reagent for determination of reducing sugar. Anal Chem 31: 426-428.

12. European Brewery Conversion (1987) Free amino nitrogen-ninhydrin colorimetric method: Analytica-EBC. (4thedn), Brauerei-und GetrankeRundschau, Zurich.

13. Martinez-Serna MD, Villota R (1992) Reactivity, functionality, and extrusion performance of native and chemically modified whey proteins. Food Extrusion Science and Technology.

14. Mercier C, Feillet P (1975) Modification of carbohydrate components by extrusion-cooking of cereal products. Cereal Chem 52: 283-297.

15. Bhattacharya M, Hanna MA (1987) Textural properties of extrusion cooked corn starch. Lebensmittel-Wissenschaft+Technologie 20: 195-201.

16. Hutchinson RJ, Siodlak GDE, Smith AC (1987) Influence of processing variables on the mechanical properties of extruded maize. Journal of Materials Science 22: 3956-3962.

17. Halek GW, Chang KLB (1992) Effect of extrusion operation variables on functionality of extrudates. Marcel Dekker, New York.

18. Hsieh F, Grenus KM, Hu L, Huff HE (1993) Twin-screw extrusion of rice flour with salt and sugar. Cereal Chem 70: 493-498.

19. Ryu GH, Walker CE (1995) The effect of extrusion conditions on the physical properties of wheat flour extrudates. Starch-Stärke 47: 33-36.

20. Jeong HS, Toledo RT (2004) Twin-screw extrusion at low temperature with carbon dioxide injection to assist expansion: extrudate characteristics. J Food Eng 63: 425-432.

21. Smith AC (1992) Studies on the physical structures of starch-based materials in the extrusion cooking process. Marcel Dekker, New York.

22. Mulvaney SJ, Rizvi SSH (1993) Extrusion processing with suprecritical fluids. J Agric Food Chem 47: 74-82.

23. Yang SH, Peng J, Lui WB, Lin J (2008) Effects of adlay species and rice flou ratio on the physiochemical properties and texture characteristic of adlaybased extrudates. J Food Eng 84: 489-494.

24. Whalen PJ (1999) Measuring process effects in ready-to-eat breakfast cereals Cereal Foods World 44: 407-412.

25. Brent JL, Mulvaney SJ, Cohen C, Bartsch JA (1997) Thermomechanical glass transition of extruded cereal melts. J Cereal Sci 26: 301-312.

26. Colona P, Tayeb J, Mercier C (1989) Extrusion cooking of starch and starchy products. American Association of Cereal Chemists, Minnesota, USA

27. Wolfgang B, Detmold W, Hans-Peter G (1999) Potato starch technology Starch-Stärke 51: 235-242

28. Casey GP, Ingledew WM (1986) Ethanol tolerance in yeasts. Crit Rev Microbio 13: $219-280$

29. Yan S, Wu X, Dahlberg J, Bean SR, MacRitche F, et al. (2010) Properties of field-sprouted sorghum and its performance in ethanol production. J Cereal Sci 51: 374-380.

30. Casey GP, Magnus CA, Ingledew WM (1984) High-gravity brewing: effects of nutrition on yeast composition, fermentative ability, and alcohol production. Appl Environ Microbiol 48: 639-646.

31. Yan S, Wu X, MacRitchie F, Wang D (2009) Germination-improved ethano fermentation performance of high-tannin sorghum in a laboratory dry-grind process. Cereal Chem 86: 597-600

32. Lekkas C, Stewart GG, Hill A, Taidi B, Hodgson J (2005) The importance of free amino nitrogen in wort and beer. MBAA TQ 42: 113-116.

33. Mullins JT, Nesmith CC (1987) Acceleration of the rate of ethanol fermentation by addition of nitrogen in high tannin grain sorghum. Biotechnol Bioeng 30 : 1073-1076.

34. Henschke PA, Jiranek V (1993) Yeast-metabolism of nitrogen compounds: 
Citation: Myat L, Ryu GH (2013) Effect of Carbon Dioxide Injection on Physiochemical Properties and Saccharification of Extruded Corn Starch for Fermentation Substrate Preparation. J Microb Biochem Technol 5: 018-024. doi:10.4172/1948-5948.1000093

Wine Microbiology and Biotechnology. Harwood Academic Publishers, Switzerland.

35. Blateyron L, Orriz-Julien A, Sablayrolles JM (2003) Stuck fermentations: Oxygen and nitrogen requirements-importance of optimizing their addition. Aust NZ Grapegrower Winemaker 487: 73-79.

36. Zhan X, Wang D, Bean SR, Mo X, Sun XS, et al. (2006) Ethanol production from supercritical-fluid extrusion cooked sorghum. Ind Crops Prod 23: 304-310.
37. Shin HH, Park BS, Lee SH, Kim YS, Hwang JK (2005) Effects of extrusion and enzyme treatment on characteristics of whole grains. Korean Journal of Food Science and Technology 37: 15-22.

38. Solihin BW, Kim MH, Im BS, Cha JY, Ryu GH (2007) Effect of feed moisture content on enzymatic hydrolysis of corn starch in twin-screw extruder and saccharification of the dried extrudates. Food Sci Biotechnol 16: 381-385. 